TITLE:

\title{
The Distribution of Sea Cucumbers in Pulau Aur, Johore, Malaysia
}

$\operatorname{AUTHOR}(\mathrm{S})$ :

ZULFIGAR, YASIN; SIM, Y.K.; AILEEN TAN, S. H.

\section{CITATION:}

ZULFIGAR, YASIN ...[et al]. The Distribution of Sea Cucumbers in Pulau Aur, Johore, Malaysia. Publications of the Seto Marine Biological Laboratory. Special Publication Series 2007, 8: 73-86

ISSUE DATE:

2007

URL:

http://hdl.handle.net/2433/70908

RIGHT: 


\title{
The Distribution of Sea Cucumbers in Pulau Aur, Johore, Malaysia
}

\author{
Yasin ZulfigaR*, Y.K. Sim and S. H. AileEn TAN \\ Muka Head Marine Research Station, Centre for Marine \& Coastal Studies, \\ School of Biological Sciences, Universiti Sains Malaysia, 11800 Minden, Penang, Malaysia \\ Corresponding author's e-mail: zulfigarusm@yahoo.com
}

\begin{abstract}
Sea cucumbers have been harvested for centuries for human consumption. The high value of some species, the ease with which such shallow water organisms can be harvested, and their vulnerable nature due to their biology, population dynamics and habitat preferences have all contributed to overexploitation and the collapse of fisheries in some locations in Malaysia. Sea cucumbers are susceptible to overexploitation due to their late maturity, density-dependent reproduction, and low rates of recruitment. Although sea cucumbers are generally widely distributed, with some species occurring throughout entire ocean basins, most species have very specific zone within reef habitats. An investigation at the Pulau Aur group (about $65 \mathrm{~km}$ east of mainland Mersing, Johore, Malaysia; in the Johor Marine Park) has been conducted using wandering transects to re-appraise the local holothuroid biodiversity pattern according to habitat and depth. Preliminary results show that three families, eight genera and 20 species of sea cucumbers were found in the 13 locations surveyed in Pulau Aur, Pulau Dayang, Pulau Lang and Pulau Pinang, during the survey from September 5 12, 2005. The dominant family found was Holothuriidae (12 species) followed by Stichopodidae ( 5 species). The most dominant species in the four islands were Holothuria edulis and Stichopus chloronotus, found abundantly on sand and rubble substrates from a wide range of depth (4-20m). Eleven of the species found were reported for the first time in the study sites. Pulau Aur, Pulau Dayang and Pulau Pinang islands exhibited a high diversity in sea cucumber population (12 species found in each island) while only 6 species of sea cucumbers were recorded in Pulau Lang. Detail of the coral reefs at the islands is given to provide a better understanding of the habitat preference of sea cucumbers in the main reef areas around the islands. Results of analysis combining habitat and sea cucumber populations show that some species can only be found in specific habitats and depths, for instance Thelenota anax (size: $30-40 \mathrm{~cm}$ ) can only be found in sandy areas at depths below $16 \mathrm{~m}$. The distribution patterns and results of data collected in the marine park where the sea cucumber fishery is prohibited and other marine resources are protected, is provided here to further the knowledge of the area and as a model for conservation purposes.
\end{abstract}

Key words: sea cucumbers, Holothuroidea, distribution, Pulau Aur group, photographic guide

\section{Introduction}

Sea cucumber fisheries are growing worldwide, leading to overexploitation in most tropical IndoPacific countries (Conand 1999, 2004a). For that reason, FAO held a symposium on exploitation, management and aquaculture (Lovatelli et al., 2004) and CITES focused attention on conservation of these animals at a meeting in Malaysia in 2004. These efforts have not had a direct impact on the conservation of sea cucumbers in Malaysia because sea cucumber fishery is the main source of livelihood in some areas, like Sabah and no regulation or rules govern the sea cucumber fisheries (Baine and Choo, 1999). The high values of the sea cucumber species, the ease of harvesting from shallow water, and their vulnerable nature contribute to overexploitation in Malaysian waters.

The Pulau Aur group is a tropical offshore island group, $67 \mathrm{~km}$ east of Mersing, Johore. Pulau Aur is comprised of several islands namely Pulau Aur, Pulau Dayang, Pulau Pinang and Pulau Lang. 
Both the Pulau Aur group and Pulau Pemanggil which is $15 \mathrm{~km}$ northwest of Pulau Aur, belong to the Johor Marine Park. Most of the rocky islands are well forested and have isolated coconut plantations. With deep, clear water, healthy corals and regular encounters with large pelagic species, these islands have the potential to become international diving attractions.

Pulau Aur was selected as the survey location of sea cucumbers as the islands in the lower part of the South China Sea have been designated as Marine Parks (Pulau Besar, Pulau Aur and Pulau Tinggi) where sea cucumber fishery is prohibited and all the marine resources are protected. The intent of the survey is to give a precise account of the biodiversity of sea cucumbers in their natural habitats and to provide references and information for the conservation of the sea cucumbers throughout Malaysian waters.

\section{Materials and Methods}

Thirteen reefs, which are located around the Pulau Aur Archipelago, Johore were surveyed using the wandering transect method (Fig. 1 and Table 1). The observation of sea cucumber species found in the study sites was done using SCUBA diving to depths of 0-30m. The methods used were mainly qualitative, since it was unrealistic to carry out quantitative surveys on all the sites within the available time. The survey was conducted both during the night and day since many of the sea cucumber species are nocturnal.

Topography data of each sampling locations was recorded, including the reef profile, the dominant fauna and the underwater features of the main reef areas around the islands. A summary of the reef characteristics was made based on scientific surveys and underwater photographic records taken to determine the details and structure of the sites. Line transects and underwater quadrates were used to determine the extent and status of the reefs. The results were then analysed and a reef profile of the area was constructed. The description and status of the typical reefs in each area was used to assess the type of the sea cucumber species associated with different types of natural habitats.

After some initial exploratory dives, checklists of the commonly seen sea cucumber species were drawn up on matt-surface rigid diving slate 5. These lists were continually updated as more reefs were investigated. Similar sheets were used for making ecological notes such as depth, morphology, habitat and substrate types and number of species. Distances of survey area were recorded and the numbers of the same species were converted into Relative Abundance unit (individual per 100m²). Colour photographs of living specimens were taken after the specimens had been transferred to a container filled with seawater and menthol crystal (see appendix), to achieve a natural body form. Colour photographs of living organisms taken with scale are of particular use when identifying species, since preserved materials often loose colour and shape.

The sea cucumbers, which could not be identified underwater, were brought to the laboratory for further investigation on their morphology, spicules and mitochondrial DNA. Further description of the morphology of the sea cucumbers and photographic records were made. Representative samples were preserved in $70 \%$ ethanol as final solution preservative (Lincoln and Sheals, 1979) and stored in Muka Head Marine Research Station, Universiti Sains Malaysia.

\section{Results}

\section{Location and type of coral reefs in Pulau Aur, Johore}

Thirteen locations were surveyed in the Pulau Aur group from September 5-12, 2005. Figure 1 shows the locations of the sampling sites. The location of the coral reefs is given in Table 1 with the reef types described in Table 2 . 


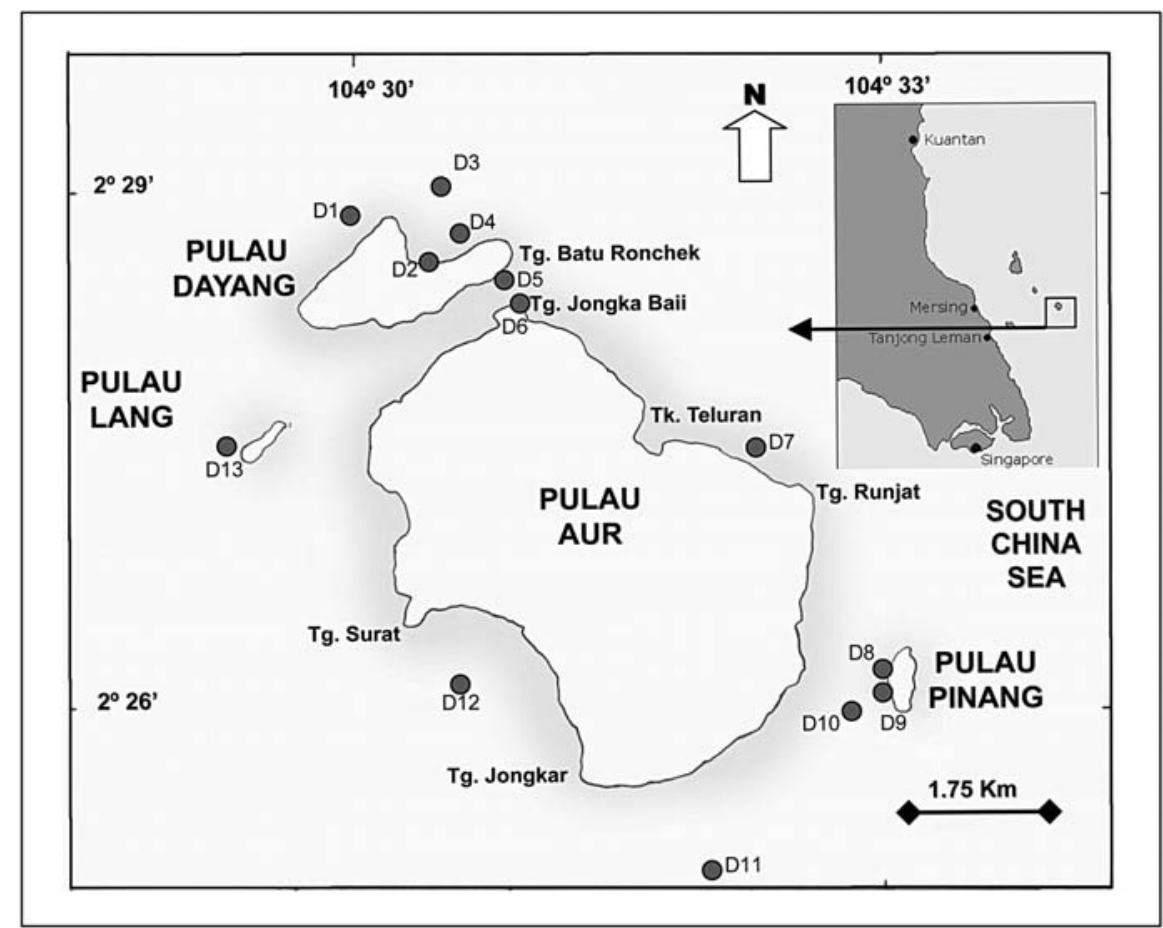

Fig. 1 The sampling locations in the Pulau Aur group, Johore.

Table. 1 The latitude and longitude of the sampling locations in the Pulau Aur group, Johore.

\begin{tabular}{lllccc}
\hline Code & \multicolumn{1}{c}{ Location name } & Latitude & Longitude & $\begin{array}{c}\text { Area } \\
\text { coverage } \\
\left(\mathbf{m}^{2}\right)\end{array}$ & Depth (m) \\
\hline D1 & Pulau Dayang (Northwest) & $2^{\circ} 28^{\prime} 54.0^{\prime \prime} \mathrm{N}$ & $104^{\circ} 29^{\prime} 55.8^{\prime \prime} \mathrm{E}$ & 40 & 15 \\
D2 & Pulau Dayang (North) & $2^{\circ} 28^{\prime} 43.5^{\prime \prime} \mathrm{N}$ & $104^{\circ} 30^{\prime} 11.8^{\prime \prime} \mathrm{E}$ & 100 & 12 \\
D3 & Pulau Dayang - Rayner's Rock & $2^{\circ} 28^{\prime} 55.0^{\prime \prime} \mathrm{N}$ & $104^{\circ} 30^{\prime} 20.9^{\prime \prime} \mathrm{E}$ & 30 & 19 \\
D4 & Pulau Dayang (North) - Teluk Jawa & $2^{\circ} 28^{\prime} 42.2^{\prime \prime} \mathrm{N}$ & $104^{\circ} 30^{\prime} 15.3^{\prime \prime} \mathrm{E}$ & 150 & 11 \\
D5 & Pulau Aur (North) & $2^{\circ} 28^{\prime} 30.0^{\prime \prime} \mathrm{N}$ & $104^{\circ} 30^{\prime} 47.5^{\prime \prime} \mathrm{E}$ & 50 & 12 \\
D6 & Pulau Aur (North) - Teluk Kador & $2^{\circ} 28^{\prime} 19.4^{\prime \prime} \mathrm{N}$ & $104^{\circ} 30^{\prime} 46.8^{\prime \prime} \mathrm{E}$ & 50 & 12 \\
D7 & Pulau Aur (East) & $2^{\circ} 27^{\prime} 32.4^{\prime \prime} \mathrm{N}$ & $104^{\circ} 31^{\prime} 49.2^{\prime \prime} \mathrm{E}$ & 50 & 12 \\
D8 & Pulau Pinang (West) - Tanjong Bercium & $2^{\circ} 26^{\prime} 17.6^{\prime \prime} \mathrm{N}$ & $104^{\circ} 32^{\prime} 38.6^{\prime \prime} \mathrm{E}$ & 50 & 25 \\
D9 & Pulau Pinang (West) & $2^{\circ} 26^{\prime} 05.7^{\prime \prime} \mathrm{N}$ & $104^{\circ} 32^{\prime} 38.6^{\prime \prime} \mathrm{E}$ & 30 & 20 \\
D10 & Pulau Pinang (Southwest) & $2^{\circ} 28^{\prime} 02.2^{\prime \prime} \mathrm{N}$ & $104^{\circ} 32^{\prime} 39.3^{\prime \prime} \mathrm{E}$ & 100 & 19 \\
D11 & Pulau Pinang - Pinnacles 1 & $2^{\circ} 25^{\prime} 09.0^{\prime \prime} \mathrm{N}$ & $104^{\circ} 31^{\prime} 59.9^{\prime \prime} \mathrm{E}$ & 100 & 30 \\
D12 & Pulau Aur (Southwest) - Teluk Dalam to & $2^{\circ} 26^{\prime} 03.7^{\prime \prime} \mathrm{N}$ & $104^{\circ} 30^{\prime} 42.6^{\prime \prime} \mathrm{E}$ & 200 & 18 \\
& Tanjong Jongkar & & & & 10 \\
D13 & Pulau Lang -Tanjong Lang & $2^{\circ} 27^{\prime} 39.9^{\prime \prime} \mathrm{N}$ & $104^{\circ} 29^{\prime} 08.1^{\prime \prime} \mathrm{E}$ & 50 & \\
\hline
\end{tabular}


Table. 2 The reef types commonly found in the Pulau Aur group.

\begin{tabular}{|c|c|c|}
\hline Reef Type & Location & Description \\
\hline Fringing reef & $\begin{array}{l}\text { - Pulau Dayang (North) (D2) } \\
\text { - Pulau Dayang (North): Teluk Jawa (D4) } \\
\text { - Pulau Aur (North): Teluk Kador (D6) } \\
\text { - Pulau Aur (Southwest): } \\
\text { Teluk Dalam to Tanjong Jongkar (D12) }\end{array}$ & $\begin{array}{l}\text { Most of these reefs lie close to the sandy } \\
\text { beaches and at the centre of bays on the islands. } \\
\text { They fringe the shores that gradually slope to } \\
\text { the sea and typify most of the reefs in the Pulau } \\
\text { Aur group. A typical cross section of the reef } \\
\text { can be described as an expanse of reef flat that } \\
\text { lies in the intertidal zone adjacent to the } \\
\text { shoreline. This then gradually slopes to the reef } \\
\text { edge where the gradient becomes steeper. The } \\
\text { bottom of the slope is usually sandy. The richest } \\
\text { coral area is found near the reef edges. }\end{array}$ \\
\hline Escarpment reef & $\begin{array}{l}\text { - Pulau Lang: Tanjong Lang (D13) } \\
\text { - Pulau Aur (East) (D7) } \\
\text { - Pulau Aur (North) (D5) } \\
\text { - Pulau Pinang (West): } \\
\text { Tanjong Bercium (D8) } \\
\text { - Pulau Pinang (West) (D9) } \\
\text { - Pulau Dayang: Rayner's Rock (D3) }\end{array}$ & $\begin{array}{l}\text { These reefs are found next to steep rocky } \\
\text { outcrops. The outcrops often extend below the } \\
\text { waters surface. These escarpment reefs may also } \\
\text { form on the rocky outcrops away from the main } \\
\text { islands such as at Rayner's rock near Pulau } \\
\text { Dayang. Here encrustations of corals form on } \\
\text { the submerged substrates. Areas protected from } \\
\text { high wave impacts usually harbour the larger } \\
\text { and more elaborate coral colonies. Below this } \\
\text { zone soft corals may predominate. }\end{array}$ \\
\hline Submerged reef & $\begin{array}{l}\text { - Pulau Pinang: Pinnacles } 1 \text { (D11) } \\
\text { - Pulau Pinang (Southwest) (D10) }\end{array}$ & $\begin{array}{l}\text { Several reefs at Pulau Aur lie away from the } \\
\text { islands and form submerged reefs. These are } \\
\text { associated with rock formations that lie below } \\
\text { the sea surface. Fishermen or divers sometimes } \\
\text { mark the locations of these reefs and the reef } \\
\text { peaks can sometimes be observed from the } \\
\text { surface where sporadic colonies of hard corals } \\
\text { predominate. In the shaded and deeper locations } \\
\text { gorgonian sea fans and soft corals form the main } \\
\text { fauna. These reefs are often subjected to strong } \\
\text { currents. }\end{array}$ \\
\hline Patch reefs & - Pulau Dayang (Northwest) (D1) & $\begin{array}{l}\text { Interspersed throughout the island group are } \\
\text { patch reefs. Coral rubble and coralline algae that } \\
\text { are cemented together and form the main } \\
\text { substrate. The reef forms patches that may lie in } \\
\text { either shallow or deeper waters, which } \\
\text { determines the presence of hard corals in the } \\
\text { area. Patch reefs harbour special kinds of fauna, } \\
\text { where algal and soft coral patches are common } \\
\text { a higher density of nudibranch molluscs is } \\
\text { usually found. }\end{array}$ \\
\hline
\end{tabular}

\section{The distribution of sea cucumbers in the Pulau Aur group}

The results of the surveys are shown in Table 3. Three families, nine genera and 20 species were recorded in the study sites. The most dominant family found was Holothuriidae (12 species) followed by Stichopodidae ( 5 species). The most common genus observed was Holothuria spp. (5 species), followed by Actinopyga spp. (4 species). The most abundant or common sea cucumber recorded was Stichopus chloronotus and Holothuria edulis, which were found on sandy, rocky and rubble areas in 


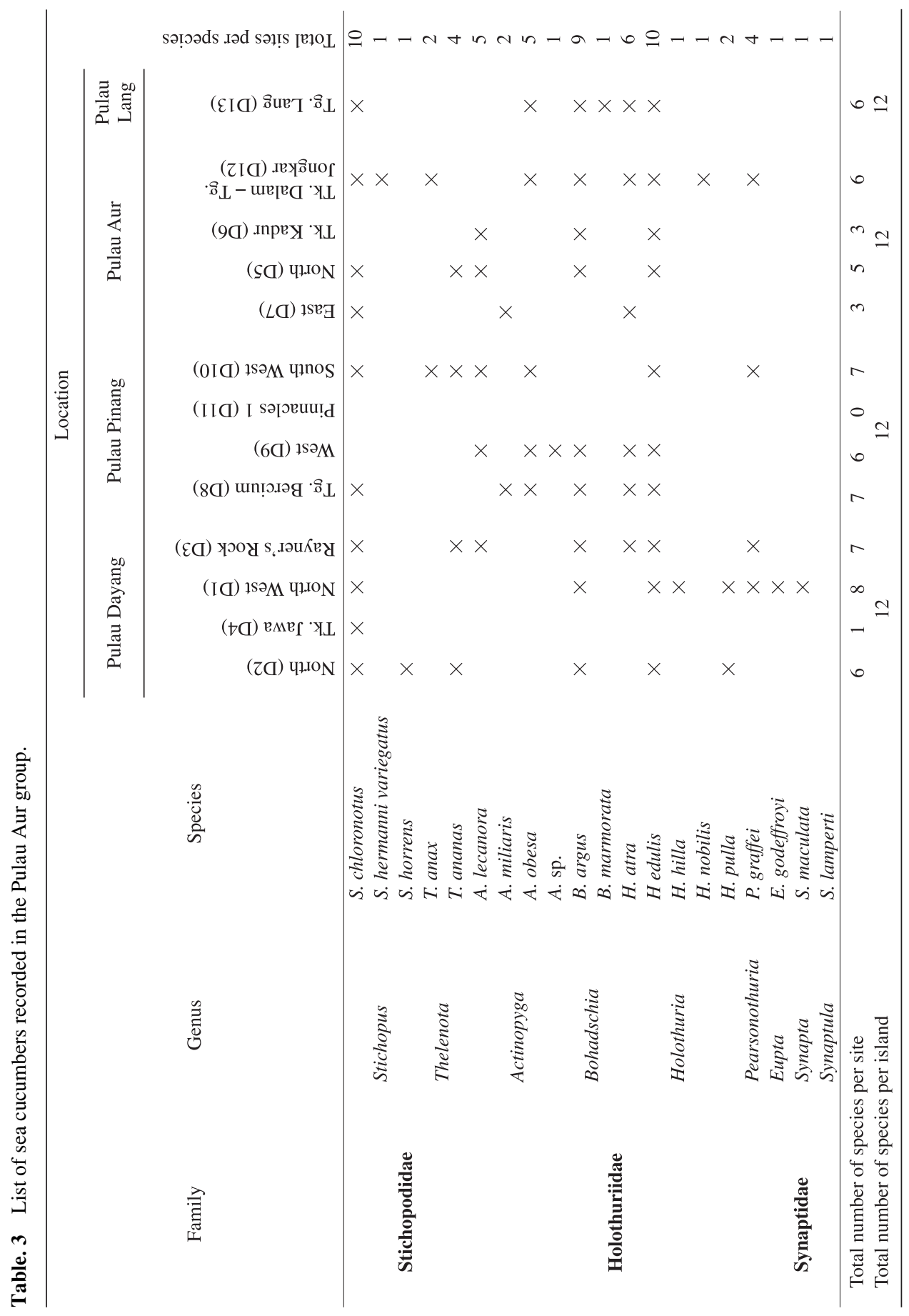


ten of the surveyed reefs. S. hermanni variegates, S. horrens, Actinopyga sp., Bohadschia marmorata, Holothuria hilla, H. nobilis, Eupta godeffroyi, Synapta maculata and Synaptula lamperti were considered rare species because they were reported only in one location.

From the four islands surveyed in the Pulau Aur group, Pulau Dayang, Pulau Pinang and Pulau Aur exhibited higher biodiversity of sea cucumber population than Pulau Lang (Fig. 2). All seven genera of sea cucumbers recorded were found in Pulau Dayang and Pulau Pinang, while six genera of sea cucumbers were recorded in Pulau Aur. Only 4 genera and 6 species of sea cucumbers were found inhabiting Pulau Lang, the smallest island in the Aur Archipelago, located west of the main island. Rayner's Rock of Pulau Dayang showed the highest biodiversity area of sea cucumbers in Pulau Dayang with six genera and seven species of sea cucumbers (Fig. 3). Only one species of sea cucumber was recorded in Teluk Jawa. The Tanjung Bercium and south-western sampling locations in Pulau Pinang were consider rich in diversity, five genera and seven species of sea cucumbers were reported in both sites compared to Pinnacles 1, the other site on the same island, where no sea cucumbers were found. At Pulau Aur, the main island in the group, six genera and nine species of sea cucumbers were found from Teluk Dalam to Tanjong Jongkar, which is located on the southwestern part of the island. This area showed the highest biodiversity of sea cucumbers among the 13 sampling locations in the Pulau Aur Archipelago. Only one location was surveyed in Pulau Lang due to the size of the island. Four genera and six species of sea cucumbers were found.

The majority of the sea cucumber species were found on sandy substrates (45.4\%), followed by coral substrates (18.5\%) (Fig. 4). Most of the species found on sandy substrate belonged to the order Aspidochirotida, which contains the largest and most conspicuous holothurians. They ingest sand and digest some of the associated organic materials. Habitat preference was different between species, even those found living on the same reef flat; for example $H$. atra and Thelenota anax seemed to prefer exposed soft sandy bottoms while Perasonothuria graffei was observed in areas with a combination of boulders, sand and live corals. S. horrens occupied areas scattered with Porites sp. Coral boulders, using the boulders for concealment during the day and foraging on the soft sandy area around them. Species Synaptula lamperti from the Family Synaptidae was found only on sponges.

The majority $(40.1 \%)$ of the sea cucumbers were collected between the depths of $16 \mathrm{~m}$ and $20 \mathrm{~m}$, $16.3 \%$ were found at depths between $21 \mathrm{~m}$ and $25 \mathrm{~m}$ (Fig. 5). We found that S. chloronotus and $H$. edulis were abundant on the sand substrate and rubble area from a wide range of depths $(4 \mathrm{~m}-20 \mathrm{~m})$ while $P$. graffe $i$ was observed in areas with live coral down to the depth of $26 \mathrm{~m}$ but were not observed on the deeper sandy area of the reef bottom. Other species like H. atra, A. lecanora, A.miliaris and $T$. ananas were also observed on the reef flats and shallow reef areas. A. obesa, B. argus and T. anax, the biggest sea cucumber species found in Malaysian waters, were observed in the deeper area $(26 \mathrm{~m}$ and below). Most of the sea cucumbers species encountered during the daytime were found either in the exposed sandy area, under rocks or in coral crevices. Some of the sea cucumbers such as S. horrens were more active at night. Most of the nocturnal species were observed to be active during the early quarter of the night but further study on this has to be carried out. Most of the sea cucumbers observed were feeding on organic materials, microorganisms or nutrients in the sand.

\section{Discussion}

The Pulau Aur group consists of the outermost islands of the Johore Archipelago and is designated as a marine park, situated on the east coast of Peninsular Malaysia. Pulau Aur is unaffected by runoff from rivers of the peninsular coast and therefore exhibits diverse and developed coral communities. A 1999 survey of sea cucumber diversity in the Pulau Aur group, conducted by Zulfigar and Tan recorded six genera and 13 species of sea cucumbers. The dominant genus found was 


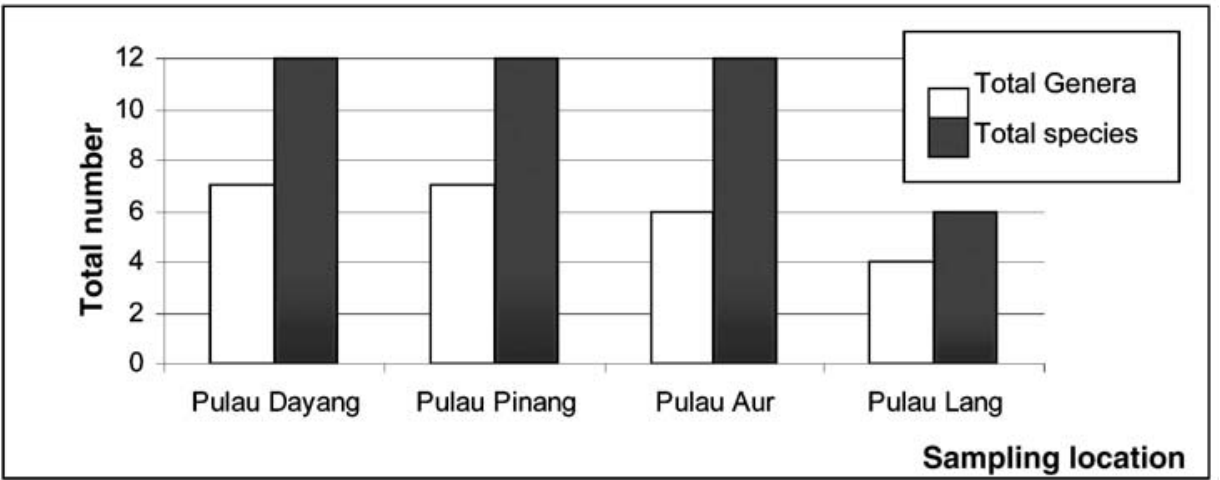

Fig. 2 Total number of genera and species of the sea cucumbers (Holothuroidea) collected from the four different islands in the Pulau Aur group.

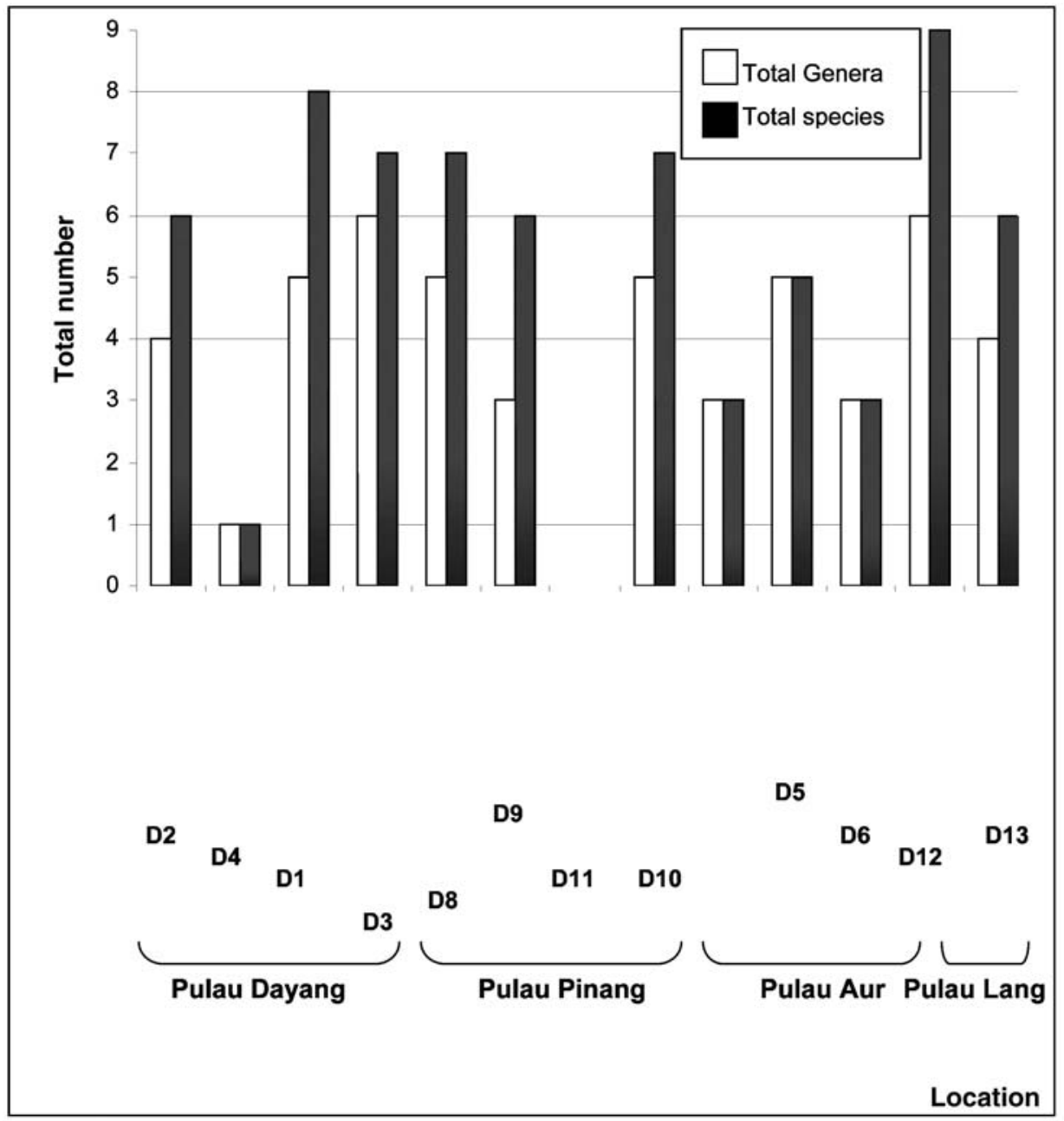

Fig. 3 The total number of genera and species of the sea cucumbers (Holothuroidea) collected from the reefs in the Pulau Aur group. 


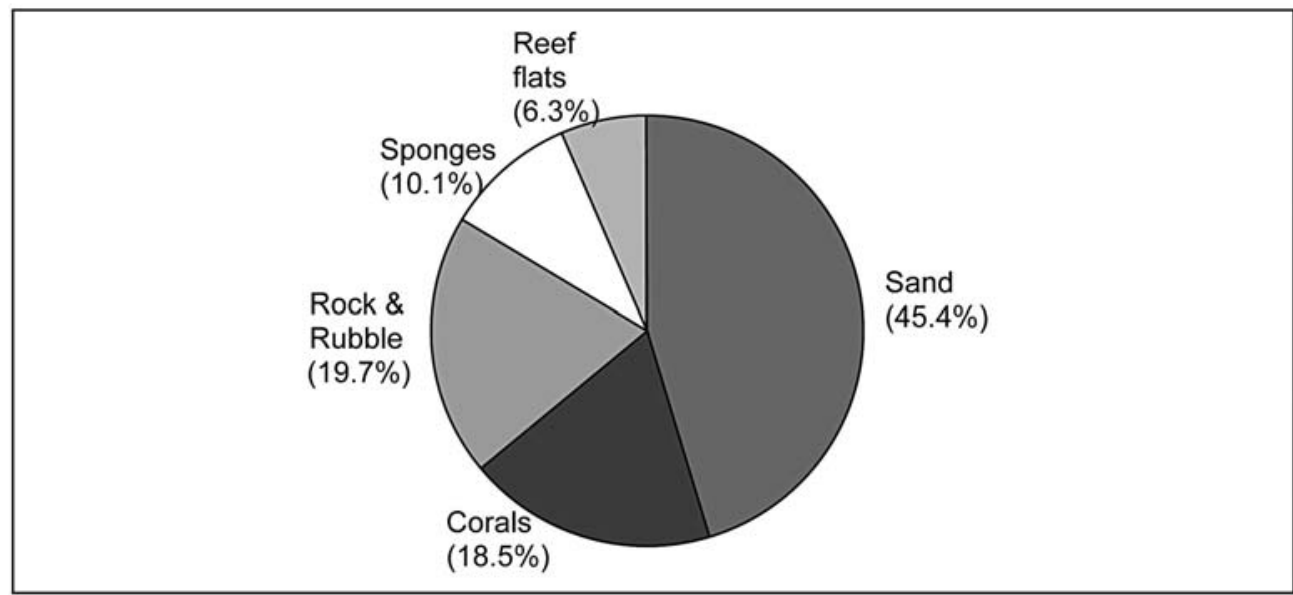

Fig. 4 The percentage of the sea cucumber samples collected from the different substrates found in the Pulau Aur group.

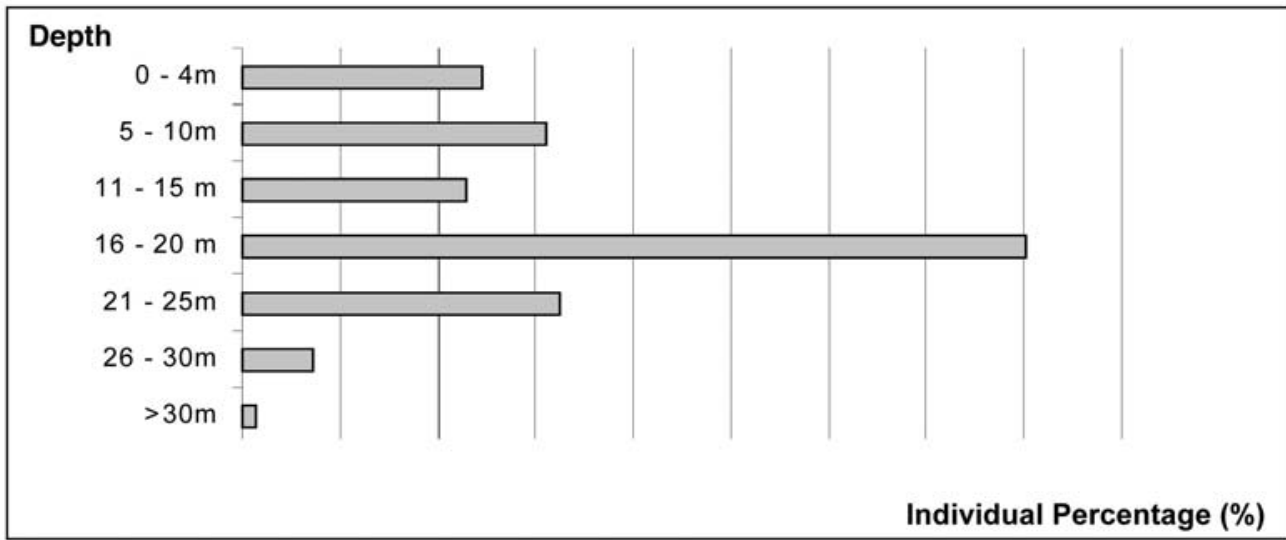

Fig. 5 The percentage of the sea cucumber samples collected from different depths in the Pulau Aur group.

Holothuria (4 species), followed by genus Bohadschia (3 species). This study has recorded 20 species of sea cucumbers in three families and nine genera in the same study area. Eleven of the species $(S$. horrens, A. lecanora, A. miliaris, A. obesa. Actinopyga sp., H. hilla, H. nobilis, H. pulla, Eupta godeffroyi, S. maculata and S. lamperti) found are reported for the first time in this area. A. echinites, Bohadschia sp.1, Holothuria sp.1 and Holothuria sp.2 which were recorded by Zulfigar and Tan (1999) in the Pulau Aur group were not found during this survey. The results in this survey were similar to the report by Zulfigar and Tan (1999), in that the most dominant species in Pulau Aur Archipelago is H. edulis, which is abundant in sandy areas in a wide depth range. The results in this survey showed that $S$. chloronotus was also one of the dominant species, found in 10 of the reefs surveyed in the Pulau Aur Archipelago.

In each island the locations with the highest diversity of sea cucumbers were protected sites located in bays. Hard Acropora coral colonies provided the best habitats for $P$. graffei in the Northwest and at Rayner's Rock, a group of rocky outcrops located at the western entrance of the straits in Pulau Dayang. Meanwhile the coral rubble and debris at the base of these rocky areas was 
the best nesting area for Holothuria spp. Only one species of sea cucumber was recorded in Teluk Jawa on the north coast of Pulau Dayang at a spot in the large bay area where terrestrial granite, coral rubble and sand occur in succession before the reef angles into deeper water. This area provided the best hiding places and food for S. chloronotus. S. horrens, only found in Pulau Dayang, occupied areas scattered with Porites sp. coral which it used as a hideout during the day and from which it foraged on the soft sandy area around the coral boulders. Most of the species from the Family Synaptidae were found on rocks and rubble substrate at the northwestern part of this island.

No sea cucumbers were found in Pinnacles 1, the submerged reefs located at the southern part of Pulau Aur. This may be due to the strong underwater current and the lack of coral cover (only occasional tabulate Acropora, encrusting species of Porites and brain corals) to provide appropriate hiding spaces. Most sea cucumbers were found in the Tanjung Bercium and Southwestern Pulau Pinang, located in the straits between Pulau Aur and Pulau Pinang. Strategic locations covered by two islands provided the best hiding and nesting places to species such as Actinopyga spp. and Bohadschia spp. The bay located in the Southwestern part of Pulau Aur (Teluk Dalam to Tanjong Jongkar) also exhibited a high diversity of the sea cucumbers compared to the other locations on the same island because the area was protected when monsoonal waves hit the coast. Species of high commercial value such as $S$. hermanni variegatus were found along the rocky and sandy areas along this coast.

Pulau Lang is the smallest island in the Pulau Aur Archipelago, lying to the west of the main island. It is a granite outcrop elongated in a northeast to southwest direction. The entire reef on this island can be classified as an escarpment reef, sloping steeply to the sea bottom. Stunted hard coral colonies are found in the shallower areas with sporadic growth on the shoulders of the submerged granite rocks. Below this soft corals and sponges can be found interspersed with the more dominant encrusting corals and coralline rubble. The island itself is exposed to the southwest monsoon and reef development is relatively poor. Only the common sea cucumbers from the order Aspidochirotida like S. chloronotus, H. atra, H. edulis, A. obesa and B. argus were found amongst the rocks and rubble.

In conclusion, only a few species of sea cucumber were found in specific habitats. The family Synaptidae was only found on sponges in the northwestern part of Pulau Dayang. S. horrens was the rarest species only found in the north part of Pulau Dayang, in areas scattered with boulders of Porites sp. coral suitable for hiding during the daytime. The rest of the species were found among the sandy bottom, rubble and rocky areas along the islands. Most of the sea cucumbers in the Pulau Aur group were found along the fringing reefs and only a few populations were established in the encampment reefs of Pulau Lang and Pulau Pinang. No sea cucumbers were observed in the submerged reefs. The topography such as bay structure, current and wave action (notably monsoonal waves) play an important role in the distribution of the sea cucumbers in the Pulau Aur group.

\section{References}

Baine, M. and Choo, P.S. 1999. Sea cucumbers fisheries and trade in Malaysia. In, Baine, M. (ed). The conservation of sea cucumbers in Malaysia. Their taxonomy, ecology and trade. Proceedings of the an International conference, 25 Feb. 1999, Department of Agriculture, Kuala Lumpur, Heriot-Watt University, Stromness. p. 49-63.

Conand, C. 1999. Manuel de qualité des holothuries commerciales du Sud-Quest de I'Océan Indien. Commission Océan Indien, 39 pp.

Conand, C. 2004. Present status of world sea cucumber resources and utilisation: an international overview. In, Lovatelli, A., Conand, C., Purcell, S., Uthicke, S., Hamel, J.F. and Mercier, A. (eds). Advances in sea cucumber aquaculture and management. FAO Fisheries Technical Paper No. 463, 13-23.

Lincoln, R.J. and Sheals, J.G. 1979. Invertebrate animals - Collection and Preservation. British Musuem (Natural History) and Cambridge University Press. 
Lovatelli, A., Conand, C., Purcell, S., Uthicke, S., Hamel, J.F. and Mercier, A. (eds). (2004). Advances in sea cucumber aquaculture and management. FAO Fisheries Technical Paper No. 463, 425 pp.

Zulfigar, Y. and Tan, S.H. 1999. Biodiversity of sea cucumber in the lower part of the South China Sea. In Saadon, M.N., Abdullah, S.A., Sheriff, S. and Ariffin, N.A. (eds), Proceedings of the 10th Japanese Society for Promotion of Sciences/Vice Chancellor Council Joint Seminar on Marine and Fisheries Sciences. Kolej University, Terengganu. pp. 74-83 
Appendix: A Photographic Guide to Pulau Aur Holothuroidea.

\section{Family Stichopodidae}
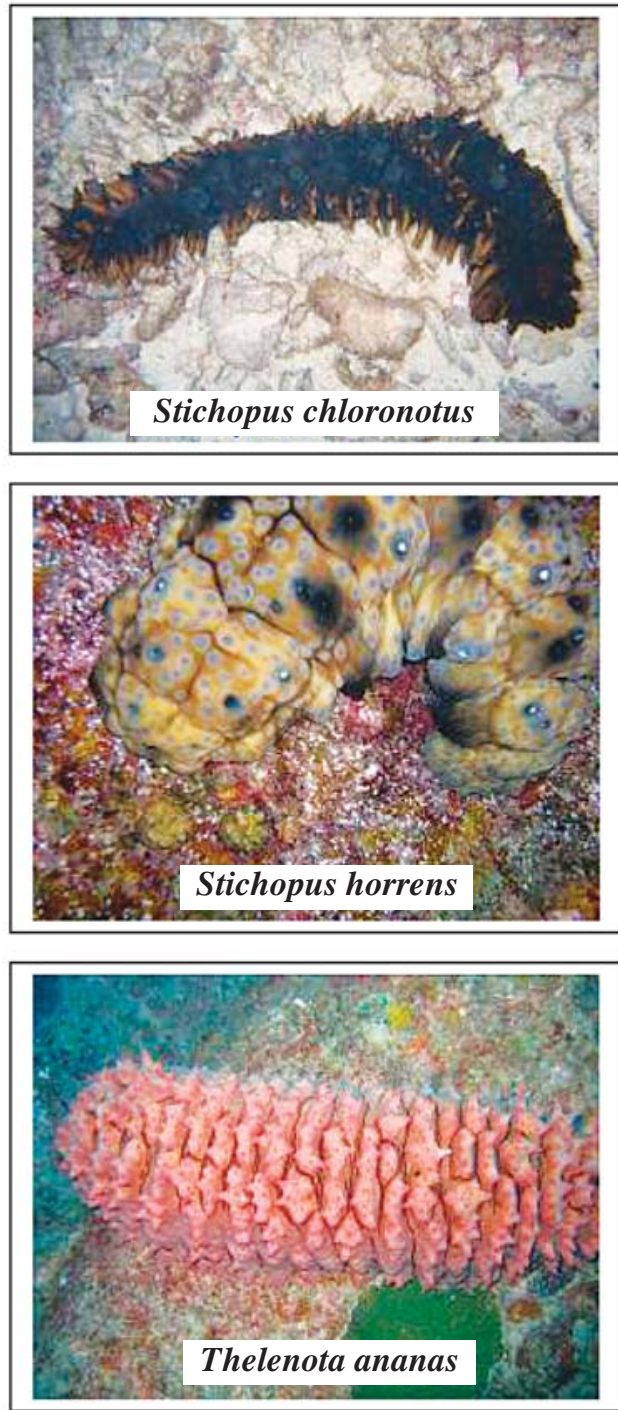
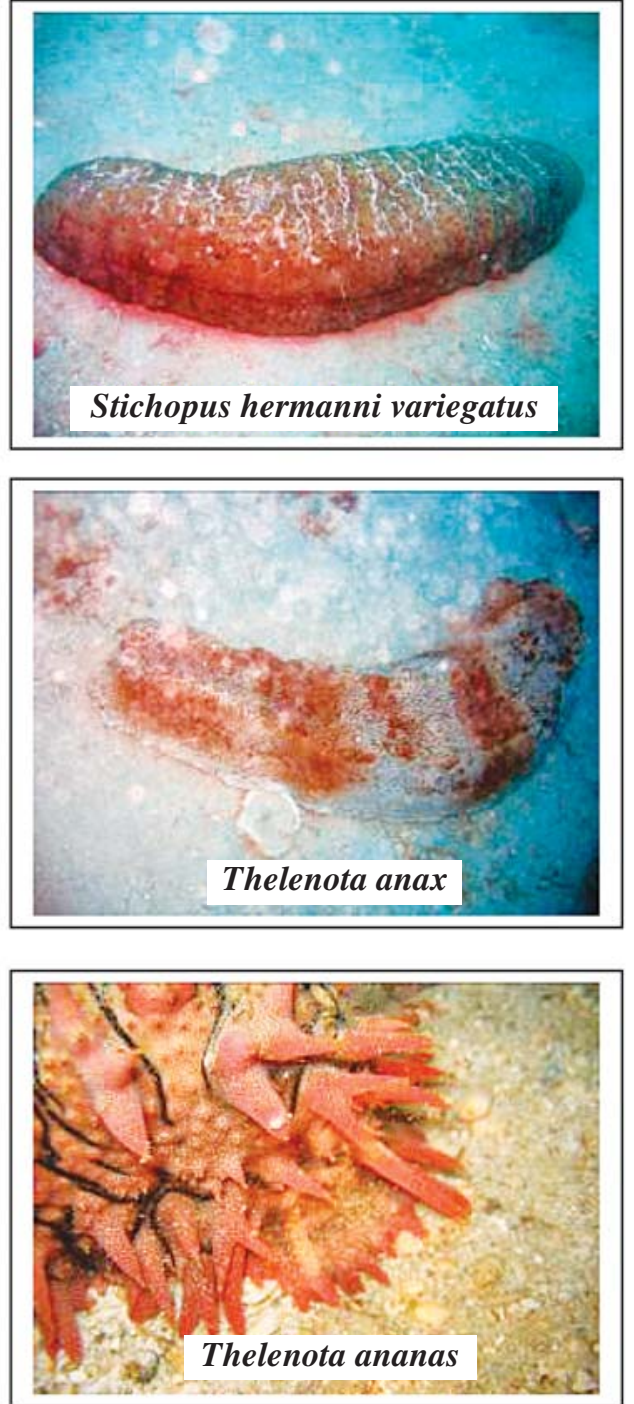
Family Holothuroidea I
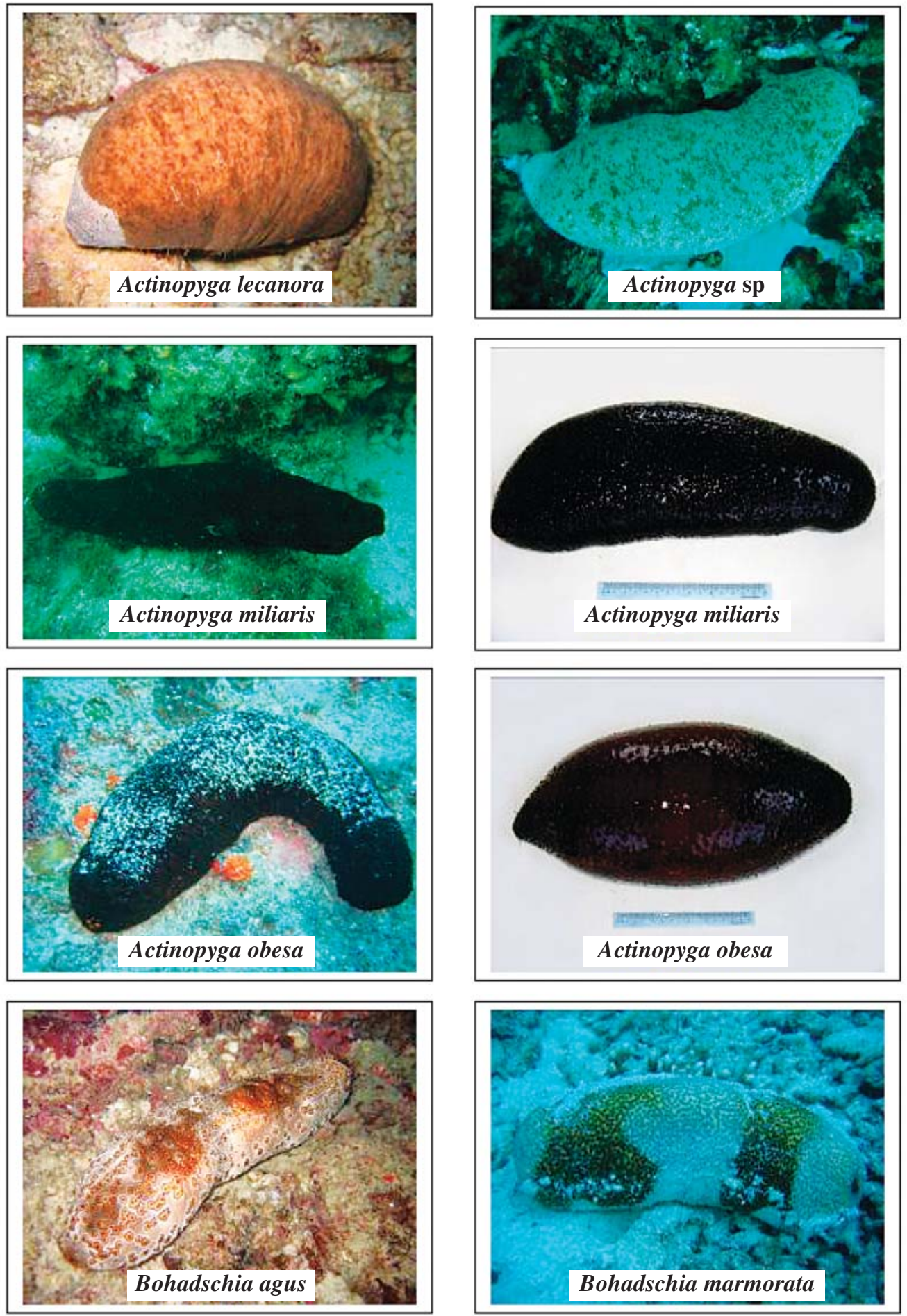
Family Holothuroidea II
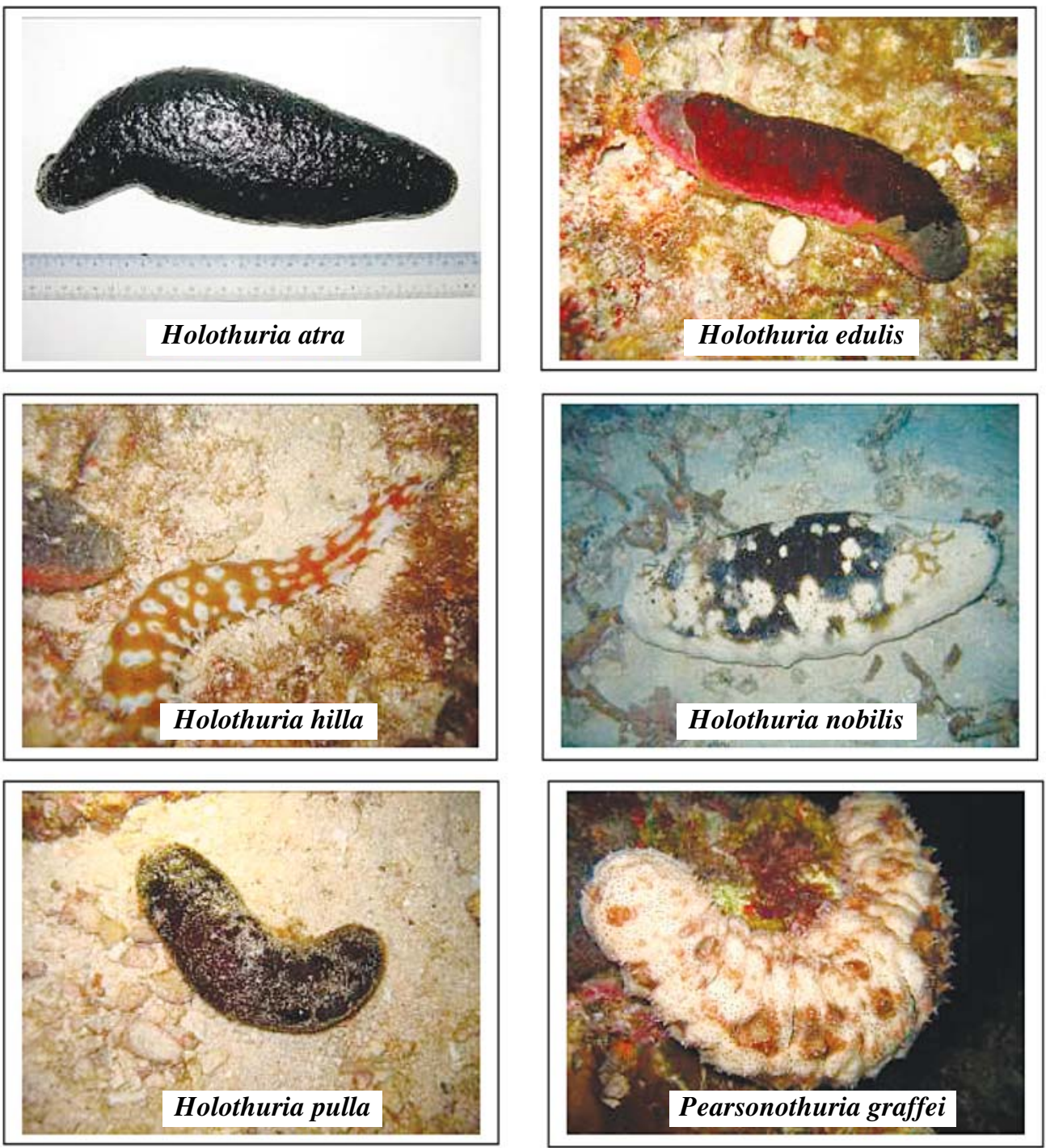
Family Synaptidae
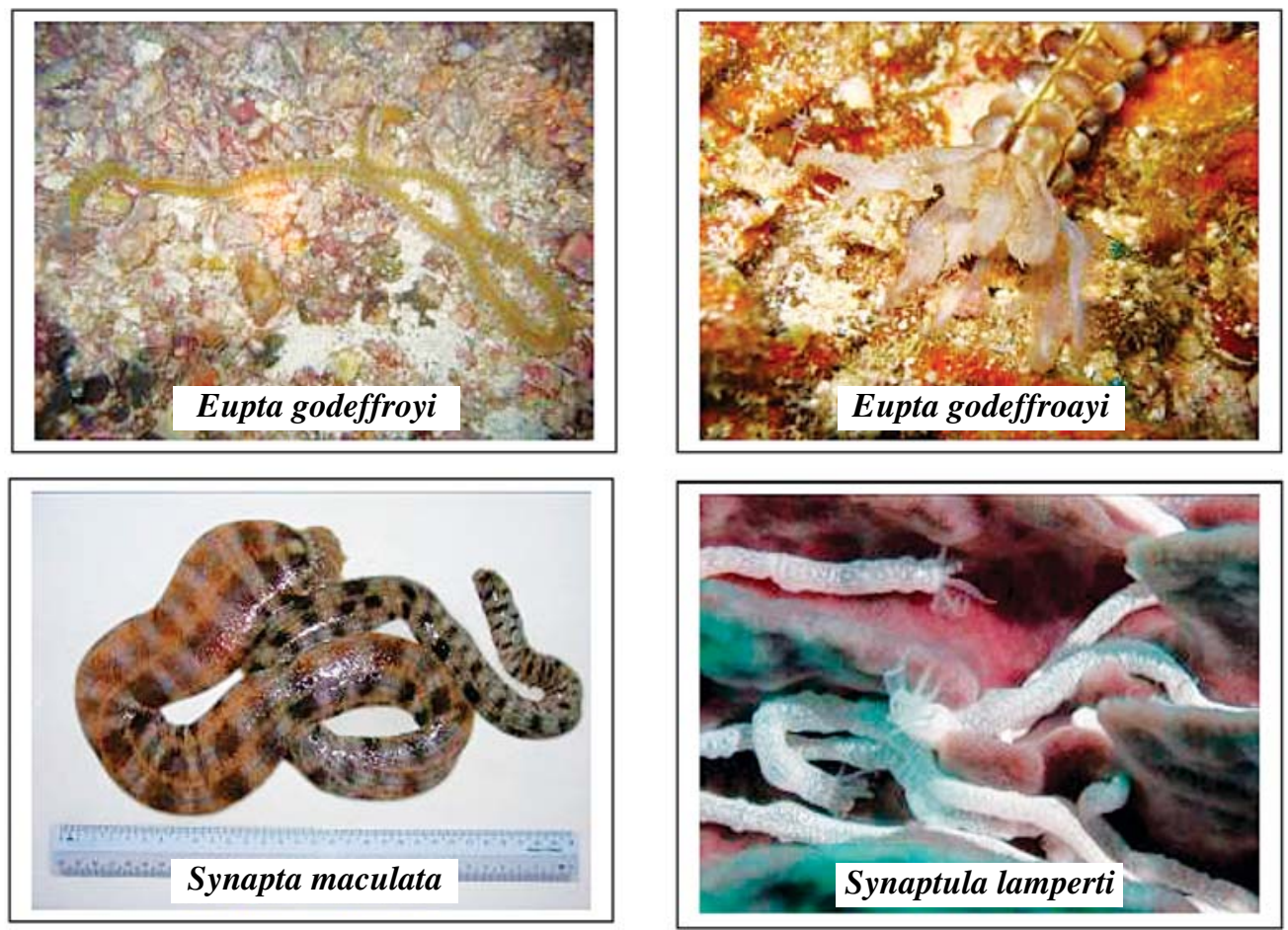